\title{
USE OF AIC AND BIC IN DESORPTION ISOTHERMS OF TAMARIND SEEDS (Tamarindus indica L.)
}

\author{
Weder N. Ferreira Junior ${ }^{1 *}$, Osvaldo Resende ${ }^{1}$, Gleyce K. I. Pinheiro', \\ Ligia C. de M. Silva ${ }^{1}$, Eduarda R. Costa ${ }^{1}$
}

${ }^{1 *}$ Corresponding author. Instituto Federal de Educação, Ciência e Tecnologia Goiano - Campus Rio Verde/ Rio Verde - GO, Brasil.
E-mail: wedernunesiftm@gmail.com | ORCID ID: https://orcid.org/0000-0002-2931-9352

\section{KEYWORDS}

water activity, hygroscopicity, Cavalcanti Mata.

\begin{abstract}
The knowledge of hygroscopicity is essential for the storage of tamarind seeds, but there is a limitation of a judicious statistical parameter to define the best mathematical model to adjust the isotherms of plant products. Therefore, this study aimed to determine the desorption isotherms of tamarind seeds and test the Akaike information criterion (AIC) and Schwarz Bayesian information criterion (BIC) for choosing the best mathematical model. Seeds with an initial moisture content of $21.00 \pm 0.10 \%$ dry basis $(\mathrm{db})$ were dried at $45{ }^{\circ} \mathrm{C}$ until they reached moisture contents of $17.27 \pm 0.10,15.04 \pm 0.16,14.14 \pm 0.06$, $12.41 \pm 0.17$, and $10.52 \pm 0.12 \% \mathrm{db}$. The water activity of the product was determined by the static-indirect method at temperatures of $10,20,30$, and $40{ }^{\circ} \mathrm{C}$. Mathematical models frequently used to predict the isotherms of plant products were adjusted to the experimental data. The Cavalcanti Mata model is recommended to estimate the desorption isotherms of tamarind seeds because it presents better adjustments. The AIC and BIC criteria contribute to the choice of the model to predict the desorption isotherms of tamarind seeds.
\end{abstract}

\section{INTRODUCTION}

Tamarind (Tamarindus indica L.) seeds are rich in proteins and can be used to improve the viscosity and texture of processed foods (Sone \& Sato, 1994) and as an active ingredient in several pharmaceutical products. Its seeds cannot be used as the main component in recipes due to the high tannin content and astringent flavor, which can be reduced during processing (Ly et al., 2017).

The post-harvest knowledge is necessary to guarantee the perpetuation of the tamarind species and commercial use of seeds in the food and pharmacological industry. Seeds are a by-product of the food industry, while the pulp is the main product (Muzaffar \& Kumar, 2016). The seeds show a high moisture content after the process of extracting the fruit pulp with water because of reheating, requiring a drying process to reduce the moisture content and, consequently, the enzymatic activities and growth of microorganisms. However, there is no information to indicate adequate moisture content for their storage.

Hygroscopic equilibrium curves contribute to estimating moisture contents suitable for the beginning of the enzymatic and microorganism activity during storage, which are detrimental to the physiological and sanitary quality of the product (Hall, 1980). These curves are derived from adjustments of mathematical models to experimental data, in which several statistical parameters, such as coefficient of determination, mean relative error, estimated mean error, and chi-square test, are used to choose the best model to estimate isotherms under the study conditions.

There are some limitations regarding the use of these parameters because some of them come from analyses of model adjustments of other phenomena (Madamba et al., 1996), requiring the adoption of additional criteria in the selection of mathematical models, such as the Akaike information criterion (AIC) and the Schwarz Bayesian information criterion (BIC). AIC and BIC consist of evaluating the models according to the principle of parsimony, as the number of coefficients in the models varies (Burnham \& Anderson, 2004).

Both criteria come from the same statistical principle based on the maximum likelihood function. They consider the number of coefficients in the model, as well as the reliability of the coefficient values (Akaike, 1974; Schwarz, 1978). The mathematical models used to adjust the isotherms

\footnotetext{
${ }^{1}$ Instituto Federal de Educação, Ciência e Tecnologia Goiano - Campus Rio Verde/ Rio Verde - GO, Brasil.
} 
usually have few coefficients, but they influence the degree of adjustment of the different experimental conditions. Therefore, more criteria that consider the reliability of estimation of these coefficients must be included.

Although tamarind seeds are important in the food and pharmaceutical industry (Sone \& Sato, 1994; Ly et al., 2017), there is limited information in the literature regarding their post-harvest processing. Thus, this study aimed to determine the desorption isotherms of tamarind seeds using the static-indirect method and test AIC and BIC for choosing of the best mathematical model.

\section{MATERIAL AND METHODS}

The experiment was developed at the Laboratory of Post-Harvest of Plant Products of the Federal Institute of Education, Science and Technology Goiano-IF Goiano, located in Rio Verde, GO, Brazil. Tamarind seeds with an initial moisture content of $21.00 \pm 0.10 \%$ dry basis $(\mathrm{db})$ were used. The fruits were collected manually in the rural region of Rio Verde, GO, Brazil (17 $51^{\prime} 57^{\prime \prime} \mathrm{S}$ and $\left.50^{\circ} 50^{\prime} 05^{\prime \prime} \mathrm{W}\right)$.

Subsequently, the seeds were cleaned by separating the pulp using an industrial pulper (Tortugan) at the
Laboratory of Fruits and Vegetables of the IF Goiano, Campus Rio Verde. The seeds were submitted to drying in a forced-air ventilation oven at a temperature of $45^{\circ} \mathrm{C}$ until reaching moisture contents of $7.27 \pm 0.10,15.04 \pm 0.16$, $14.14 \pm 0.06,12.41 \pm 0.17$, and $10.52 \pm 0.12 \% \mathrm{db}$. The gravimetric method was used to monitor the drying process, in which weighings are carried out until reaching the established water levels, considering the initial seed moisture content. The moisture contents were verified by the ovendrying method at $105 \pm 1{ }^{\circ} \mathrm{C}$ for 24 hours (Brasil, 2009).

The desorption isotherms of tamarind seeds were determined using the static-indirect method, in which the water activity $\left(a_{w}\right)$ was determined using the HygroPalm AW1 equipment. Triplicate samples were used for each moisture content, with approximately $35 \mathrm{~g}$ of seeds inserted inside the equipment. The equipment was conditioned in a BOD set at $10,20,30$, and $40{ }^{\circ} \mathrm{C}$. The moisture content of the samples in the oven was determined after reading the temperature and water activity in the equipment, following the methodology of Brasil (2009).

Mathematical models frequently used to represent the hygroscopicity of plant products were adjusted to the experimental data, whose expressions are shown in Table 1.

TABLE 1. Mathematical models used to predict the hygroscopic phenomenon of tamarind (Tamarindus indica L.) seeds.

\begin{tabular}{ccr}
\hline Model designation & Model & \\
\hline $\mathrm{Xe}=\left[\ln \left(1-\mathrm{a}_{\mathrm{w}}\right) /\left(\mathrm{a} \cdot \mathrm{T}^{\mathrm{b}}\right)\right]^{1 / \mathrm{c}}$ & Cavalcanti Mata & $(1)$ \\
\hline $\mathrm{Xe}=\mathrm{a}-\mathrm{b} \cdot \ln \left[-(\mathrm{T}+\mathrm{c}) \cdot \ln \left(\mathrm{a}_{\mathrm{w}}\right)\right]$ & Chung-Pfost & $(2)$ \\
\hline $\mathrm{(} \mathrm{T})$ & & $(3)$ \\
\hline $\mathrm{T}=\left(\mathrm{a} \cdot \mathrm{b} \cdot \mathrm{a}_{\mathrm{w}}\right) \cdot \frac{}{\left(1-\mathrm{b} \cdot \mathrm{a}_{\mathrm{w}}+\left(\frac{\mathrm{c}}{\mathrm{T}}\right) \cdot \mathrm{b} \cdot \mathrm{a}_{\mathrm{w}}\right) \cdot\left(1-\mathrm{b} \cdot \mathrm{a}_{\mathrm{w}}\right)}$ & Modified GAB & $(4)$ \\
\hline $\mathrm{Xe}=\left[\exp (\mathrm{a}-\mathrm{b} \cdot \mathrm{T}) /-\ln \left(\mathrm{a}_{\mathrm{w}}\right)\right]^{1 / \mathrm{c}}$ & Modified Halsey & $(5)$ \\
\hline $\mathrm{Xe}=\left[\ln \left(1-\mathrm{a}_{\mathrm{w}}\right) /-\mathrm{a} \cdot(\mathrm{T}+273.15)\right]^{1 / \mathrm{b}}$ & Henderson & $(6)$ \\
\hline $\mathrm{Xe}=\left[\ln \left(1-\mathrm{a}_{\mathrm{w}}\right) /-\mathrm{a} \cdot(\mathrm{T}+\mathrm{b})\right]^{1 / \mathrm{c}}$ & Modified Henderson & $(7)$ \\
\hline $\mathrm{Xe}=(\mathrm{a}+\mathrm{b} \cdot \mathrm{T}) /\left[\left(1-\mathrm{a}_{\mathrm{w}} / \mathrm{a}_{\mathrm{w}}\right)\right]^{1 / \mathrm{c}}$ & Modified Oswin & $(8)$ \\
\hline $\mathrm{Xe}=\mathrm{a} \cdot\left[\mathrm{a}_{\mathrm{w}} \cdot\left(\frac{\mathrm{b}}{\mathrm{T}}\right)\right]$ & Sabbah & $(9)$ \\
\hline$X e=\exp \left\{\mathrm{a}-(\mathrm{b} \cdot \mathrm{T})+\left[\mathrm{c} \cdot \exp \left(\mathrm{a}_{\mathrm{w}}\right)\right]\right\}$ & Sigma Copace & (6)
\end{tabular}

$\mathrm{Xe}$ is the equilibrium moisture content $(\% \mathrm{db}), \mathrm{a}_{\mathrm{w}}$ is the water activity (decimal), $\mathrm{T}$ is the temperature $\left({ }^{\circ} \mathrm{C}\right)$, and $\mathrm{a}, \mathrm{b}$, and $\mathrm{c}$ are coefficients that vary according to the product.

The mathematical models were adjusted using the nonlinear regression analysis by the Gauss-Newton method. It considered the significance of regression coefficients by the t-test the 0.01 significance level. The degree of fit of each model was compared using the values of the coefficient of determination $\left(\mathrm{R}^{2}\right)$, the estimated mean error $(\mathrm{SE})$, the relative mean error $(\mathrm{P})$, and the chi-square test $\left(\chi^{2}\right)$ at the 0.01 significance level and $99 \%$ confidence interval $(\mathrm{P}<0.01)$, in addition to the AIC and BIC values.

The value of the relative mean error considered models with a value below $10 \%$, according to Mohapatra \& Rao (2005). The differences between the experimental values and those estimated by the model, together with the degree of freedom and number of observations, are used to calculate the values of the estimated mean error (SE), relative mean error $(\mathrm{P})$, and chi-square test $\left(\chi^{2}\right)$, according to the following expressions:

$$
\begin{aligned}
& \mathrm{SE}=\sqrt{\frac{\sum(\mathrm{Y}-\widehat{\mathrm{Y}})^{2}}{\mathrm{DF}}} \\
& \mathrm{P}=\frac{100}{n} \sum \frac{|\mathrm{Y}-\widehat{\mathrm{Y}}|}{Y} \\
& \chi^{2}=\sum \frac{(\mathrm{Y}-\widehat{\mathrm{Y}})^{2}}{\mathrm{DF}}
\end{aligned}
$$

Where:

$\mathrm{SE}$ is the estimated mean error (decimal);

$\mathrm{P}$ is the relative mean error (\%);

$\chi^{2}$ is the chi-square (decimal);

$\mathrm{Y}$ is the experimental value;

$\hat{\mathrm{Y}}$ is the value estimated by the model; 
$\mathrm{n}$ is the number of experimental observations, and

DF is the degree of freedom of the model (number of observations minus the number of parameters of the model).

Both AIC and BIC were used to choose the best mathematical model to predict the phenomenon. These indicators were obtained by adjusting the models in the software $\mathrm{R}$, using the nls function, in which the loglikelihood is calculated from the estimates of coefficients of the software.

The AIC allows using the principle of parsimony in choosing the best model, i.e., according to this criterion, the model with the highest number of coefficients is not always the best (Burnham \& Anderson, 2004). AIC is used to compare non-nested models or three or more models. Lower AIC values reflect a better fit (Akaike, 1974):

$$
\mathrm{AIC}=-2 \log \text {-like }+2 \mathrm{p}
$$

Where:

$\mathrm{p}$ is the number of coefficients, and log-like is the value of the logarithm of the likelihood function, considering the coefficient estimates.

The BIC also considers the set of coefficients of the model and, similarly, the lower the BIC value, the better the model will fit. It is an asymptotic criterion, whose adequacy is strongly related to the magnitude of the sample size. The penalty applied to the number of coefficients will be more stringent than the AIC for small samples (Schwarz, 1978):

$$
\mathrm{BIC}=-2 \log \mathrm{like}+\mathrm{p} \cdot \ln (\mathrm{n})
$$

Where:

$\mathrm{n}$ is the number of observations.

\section{RESULTS AND DISCUSSION}

The experimental values of water activity varied according to the increase in temperature $(10,20,30$, and 40 ${ }^{\circ} \mathrm{C}$ ) and equilibrium moisture content ( 10.52 to $\left.21.10 \% \mathrm{db}\right)$, being a variable directly proportional to these conditions (Table 2). Barbosa et al. (2016) observed similar behavior when studying desorption isotherms of Anacardium humile St. Hil. achenes by the static-indirect method.

TABLE 2. Experimental values of water activity (decimal) of tamarind (Tamarindus indica L.) seeds as a function of equilibrium moisture content and temperature.

\begin{tabular}{ccccc}
\hline $\mathrm{Xe}$ & \multicolumn{3}{c}{ Temperature $\left({ }^{\circ} \mathrm{C}\right)$} \\
\cline { 2 - 5 }$(\% \mathrm{db})$ & 10 & 20 & 30 & - \\
\hline 10.52 & 0.437 & 0.472 & 0.491 & 0.511 \\
10.74 & - & - & 0.572 & - \\
12.39 & 0.519 & - & - & 0.591 \\
12.49 & - & 0.634 & 0.653 & 0.670 \\
14.15 & - & - & - & - \\
15.04 & 0.655 & - & 0.791 & 0.812 \\
17.27 & - & - & - & - \\
20.94 & 0.857 & - & - & - \\
21.10 & - & 0.892 & & - \\
\hline
\end{tabular}

The coefficients of adjusted models showed that all models were significant at 0.01 by the t-test (Table 3 ). The coefficients of the model selected to describe the equilibrium isotherms are specific to the product or material under study, and should not be used to represent another species or material (Botelho, 2012).

The values of the coefficient of determination (Table
3 ) showed that the adjusted models presented values above 0.96. According to Madamba et al. (1996), this parameter should not be used as the sole evaluation criterion for model selection, as it uses means of positive and negative values for non-linear models, leading to extreme values. The Cavalcanti Mata model presented the highest value for $\mathrm{R}^{2}(0.9961)$. 
TABLE 3. Coefficients of the models adjusted to the hygroscopic equilibrium moisture content of Tamarind (Tamarindus indica L.) seeds with the statistical parameters coefficient of determination $\left(\mathrm{R}^{2}\right.$, decimal), estimated mean error (SE, decimal), chisquare $\left(\chi^{2}\right.$, decimal), and relative mean error $(\mathrm{P}, \%)$.

\begin{tabular}{|c|c|c|c|c|c|}
\hline Model & Coefficient & $\mathrm{P}(\%)$ & SE & $\chi^{2}$ & $\mathrm{R}^{2}$ \\
\hline Cavalcanti Mata & $\begin{array}{l}\mathrm{a}=-0.0055^{* *} \\
\mathrm{~b}=0.1291^{* *} \\
\mathrm{c}=1.8318^{* *}\end{array}$ & 1.422 & 0.232 & 0.0540 & 0.9961 \\
\hline Chung-Pfost & $\begin{array}{l}\mathrm{a}=37.2820^{* *} \\
\mathrm{~b}=5.7251^{* *} \\
\mathrm{c}=111.147^{* *}\end{array}$ & 2.072 & 0.368 & 0.1355 & 0.9901 \\
\hline Modified GAB & $\begin{array}{l}\mathrm{a}=8.2353^{* *} \\
\mathrm{~b}=0.7056^{* *} \\
\mathrm{c}=339.156^{* *}\end{array}$ & 1.818 & 0.355 & 0.1262 & 0.9892 \\
\hline Modified Halsey & $\begin{array}{l}\mathrm{a}=6.6490^{* *} \\
\mathrm{~b}=0.0063^{* *} \\
\mathrm{c}=2.8019^{* *}\end{array}$ & 3.704 & 0.654 & 0.4280 & 0.9687 \\
\hline Henderson & $\begin{array}{l}\mathrm{a}=0.00003^{* *} \\
\mathrm{~b}=1.81333^{* *}\end{array}$ & 1.931 & 0.349 & 0.1217 & 0.9904 \\
\hline Modified Henderson & $\begin{array}{l}\mathrm{a}=0.00005^{* *} \\
\mathrm{~b}=142.897^{* *} \\
\mathrm{c}=1.8356^{* *}\end{array}$ & 1.505 & 0.263 & 0.0691 & 0.9950 \\
\hline Modified Oswin & $\begin{array}{l}\mathrm{a}=12.1839^{* *} \\
\mathrm{~b}=-0.0290^{* *} \\
\mathrm{c}=3.2834^{* *}\end{array}$ & 2.980 & 0.527 & 0.2774 & 0.9797 \\
\hline Sabbah & $\begin{array}{l}\mathrm{a}=30.2324^{* *} \\
\mathrm{~b}=1.0660^{* *} \\
\mathrm{c}=0.0884^{* *}\end{array}$ & 1.116 & 0.275 & 0.0758 & 0.9945 \\
\hline Sigma Copace & $\begin{array}{l}\mathrm{a}=1.1903^{* *} \\
\mathrm{~b}=0.0031^{* *} \\
\mathrm{c}=0.7953^{* *}\end{array}$ & 2.162 & 0.351 & 0.1235 & 0.9910 \\
\hline
\end{tabular}

**Significant at $0.01 ;{ }^{\mathrm{n}}$ not significant by the t-test.

The modified Halsey model showed the highest value (0.654) for the estimated mean error (Table 3) compared to the other adjusted models, while the Cavalcanti Mata model showed the lowest value (0.232). According to Draper \& Smith (1998), the ability of a mathematical model to represent a physical process is the inversely proportional relationship to the value of the estimated mean error, i.e., the lower the value for this parameter, the better the representation of the model for the studied phenomenon.

Regarding the calculated chi-square, all models were within the $99 \%$ confidence interval (tabulated $\chi^{2}=6.571$ and 5.822 for models with 2 and 3 coefficients, respectively). The Cavalcanti Mata, modified Henderson, and Sabbah models showed lower values for the calculated chi-square $(0.0540,0.0691$, and 0.0758 , respectively).

The Sabbah model presented the lowest value for the relative mean error (Table 3), while the modified Halsey model had the highest value compared to the other adjusted models. All models can be used to predict the hygroscopicity of tamarind seeds when adopting the Mohapatra \& Rao (2005) methodology, as they have values for the relative mean error lower than $10 \%$. However, this recommendation was established in research carried out for drying kinetics, making it necessary to adjust this limit and/or use complementary criteria to select the best model to estimate isotherms.

According to the traditionally evaluated statistical parameters for choosing the model that best fits the experimental data to represent the hygroscopicity of plant products, the Cavalcanti Mata, modified GAB, modified Henderson, and Sabbah models fit the selection criteria and, therefore, represent satisfactorily the desorption isotherms of tamarind seeds.

Due to the need to include additional objective criteria to assist in selecting a single model that estimates desorption isotherms, the application of the AIC and BIC methodology was suggested in this study to select the best model that describes the sorption isotherms. In this case, the indication of the best model may be more accurate since these criteria consider other factors such as the analysis of the set of coefficients, including their degree of estimates (Akaike, 1974; Schwarz, 1978).

Ferreira Junior et al. (2018) studied the desorption isotherms of Hymenaea stigonocarpa Mart. seeds and used the AIC and BIC criteria in the mathematical modeling of the desorption isotherms of the product at different temperatures and relative humidity. The authors reported that the criteria contributed to the choice of the model for representing the phenomenon. These criteria contribute to choosing the model to be used in the adjustment in mathematical modeling studies of post-harvest processing (Gomes et al., 2018; Quequeto et al., 2019; Souza et al., 2019).

Thus, the Cavalcanti Mata model presented the lowest values for AIC and BIC (2.94 and 6.03, respectively) (Table 4) considering the use of these criteria to represent the desorption isotherms of tamarind seeds. 
TABLE 4. Values of the Akaike information criteria (AIC) and Schwarz Bayesian information criteria (BIC) for models adjusted to the hygroscopicity of tamarind (Tamarindus indica $\mathrm{L}$.) seeds.

\begin{tabular}{cccccc}
\hline Model & AIC & BIC & Model & AIC & BIC \\
\hline Cavalcanti Mata & 02.94 & 06.03 & Modified Henderson & 07.14 & 10.23 \\
Chung-Pfost & 18.06 & 21.15 & Modified Oswin & 29.53 & 32.62 \\
Modified GAB & 19.34 & 22.43 & Sabbah & 23.84 & 26.93 \\
Modified Halsey & 36.49 & 39.58 & Sigma Copace & 16.33 & 19.42 \\
Henderson & 15.51 & 17.82 & & & \\
\hline
\end{tabular}

The Cavalcanti Mata model also provided a better fit for the desorption isotherms of cowpea (Vigna unguiculata (L.) Walpers), an evergreen variety, at temperatures of 20 , 30,40 , and $50{ }^{\circ} \mathrm{C}$ and water activity from 0.10 and 0.85 (Oliveira et al., 2004). In addition to tamarind seeds, the
Cavalcanti Mata model (Figure 3) can be used to represent the hygroscopicity of seeds of paddy rice (Oryza sativa $\mathrm{L}$. cv. BRS Sertaneja) (Oliveira et al., 2014), aji pepper (Capsicum chinense L.) (Silva et al., 2015), and sorghum (Sorghum bicolor (L.) Moench) (Ullmann et al., 2016).

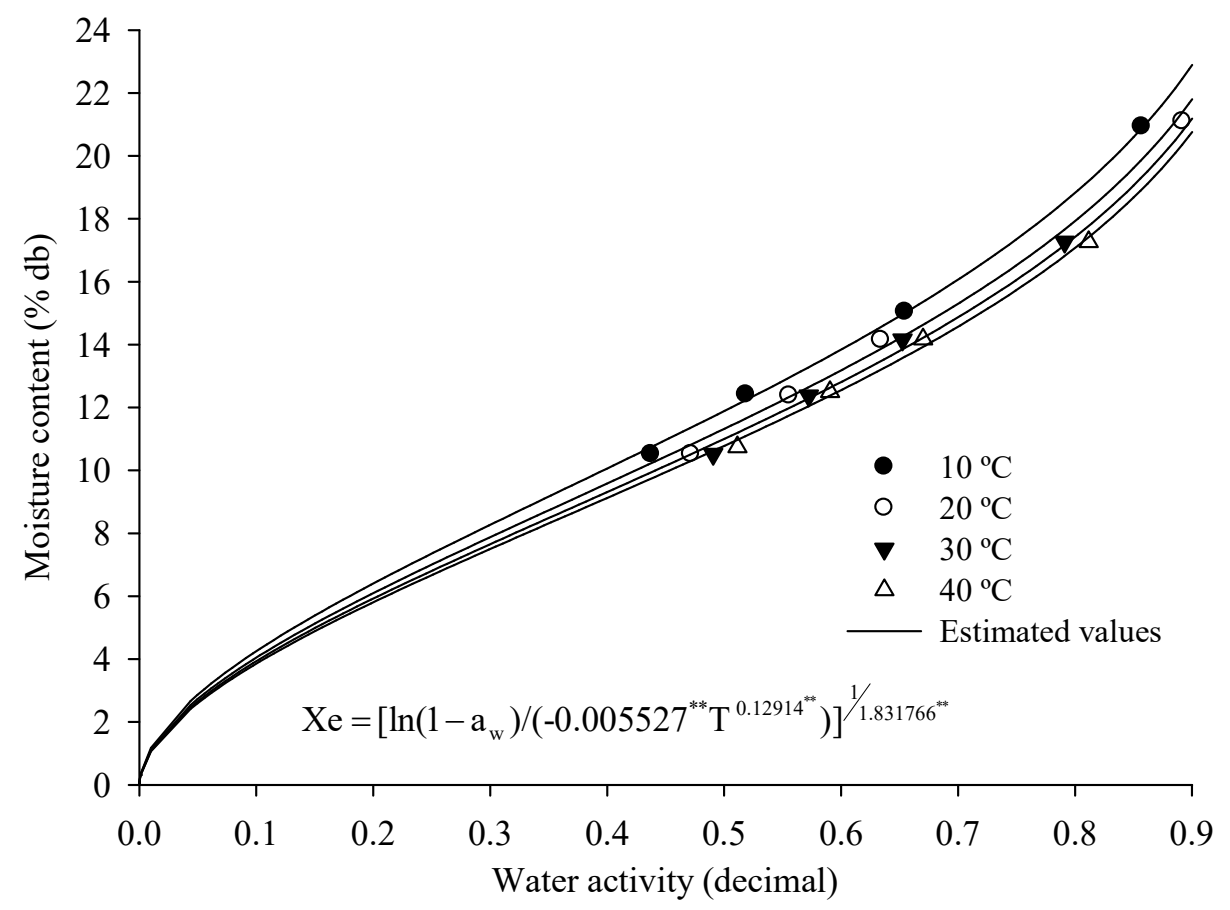

**Significant at $1 \%$ by the t-test.

FIGURE 1. Desorption isotherms estimated by the Cavalcanti Mata model for tamarind (Tamarindus indica L.) seeds at temperatures of $10,20,30$, and $40^{\circ} \mathrm{C}$.

The desorption isotherm curves estimated by the model (Figure 1) showed that, for the same range of moisture content, water activity values increase as the temperature increases. It is a response found in the isotherms of various plant products in the literature, such as yellow mombin (Spondias mombin L.) pulp in foam (Cavalcante et al., 2018), sunflower seeds (Helianthus annuus L.) (Campos et al., 2019), and brazilnuts (Bertholletia excelsa H. B. K.) (Botelho et al., 2019).

The quality and viability of stored seeds are ensured by its water activity, which is response dependent on the equilibrium moisture content, temperature, and relative humidity. The safe limit of water activity to prevent stored products from becoming susceptible to attack by microorganisms is around 0.7 (decimal); the development of pathogenic microorganisms occurs above this water activity value (Oliveira et al., 2005).

The maximum equilibrium moisture content predicted by the Cavalcanti Mata model (Figure 3) for tamarind seeds to be stored at temperatures of 10, 20, 30, and $40{ }^{\circ} \mathrm{C}$ was $16.07,15.30,14.87$, and $14.57 \% \mathrm{db}$, respectively. These high limits are due to the interactions between the water molecules and the chemical constituents of seeds, which are of approximately $16.2 \%$ proteins, $75.58 \%$ carbohydrates, and $7.06 \%$ lipids (Ly et al., 2017).

The desorption isotherms obtained for tamarind seeds had a type II sigmoid shape (IUPAC, 1985), as observed for other plant products, such as African mesquite (Prosopis africana) seeds (Ade et al., 2016), baru (Dipteryx alata Vog.) fruits (Oliveira et al., 2017), castorbean (Ricinus communis L.) (Goneli et al., 2016), purple mombin (Spondias purpurea L.) powder (Lins et al., 2017), locoto (Capsicum baccatum) (Andrade et al., 2017), and lettuce (Lactuca sativa) seeds (Zeymer et al., 2017). The type II isotherms are caused by synergistic effects of Raoult's law, capillary effects, and interactions of moisture on the material surface (Labuza \& Altunakar, 2007). 


\section{CONCLUSIONS}

The Cavalcanti Mata model is recommended to estimate the desorption isotherms of tamarind seeds.

The AIC and BIC criteria contribute to the choice of the model to predict the desorption isotherms of tamarind seeds.

The safe moisture content for storing tamarind seeds at temperatures of $10,20,30$, and $40{ }^{\circ} \mathrm{C}$ is $16.07,15.30$, 14.87 , and $14.57 \% \mathrm{db}$, respectively.

\section{ACKNOWLEDGMENTS}

The authors would like to thank IF Goiano, CAPES, FAPEG, FINEP, and CNPq for the financial support, indispensable for carrying out this study.

\section{REFERENCES}

Ade AR, Ajav EA, Raji AO, Adetayo AS, AROWORA KA (2016) Moisture sorption isotherms of Mesquite seed (Prosopis africana). Agricultural Engineering International: CIGR Journal 18(3):273-281.

Andrade ET, Figueira VG, Teixeira LP, Taveira JHS, Borém FM (2017) Determination of the hygroscopic equilibrium and isosteric heat of aji chili pepper. Revista Brasileira de Engenharia Agrícola e Ambiental 21(12):865-871. DOI: http://dx.doi.org/10.1590/18071929/agriambi.v21n12p865-871

Akaike H (1974) A new look at the statistical model identification. IEEE Transaction on Automatic Control, 19(6):716-723. DOI:

http://dx.doi.org/10.1109/TAC.1974.1100705

Barbosa KF, Sales JF, Resende O, Oliveira DEC, Zuchi J, Sousa KA (2016) Desorption isotherms and isosteric heat of 'cajuzinho-do-cerrado' achenes. Revista Brasileira de Engenharia Agrícola e Ambiental 20(5):481-486. DOI: http://dx.doi.org/10.1590/18071929/agriambi.v20n5p481-486

Botelho FM (2012) Cinética de secagem, propriedades físicas e higrscópicas dos frutos e caracterização do processo de torrefação dos grãos de Coffea canéfora. Tese Doutorado, Viçosa, Universidade Federal de Viçosa.

Botelho FM, Boschiroli Neto NJ, Botelho SCC, Oliveira GHH, Hauth MR (2019) Sorption isotherms of Brazil nuts. Revista Brasileira de Engenharia Agrícola e Ambiental 23(10):776-781. DOI: http://dx.doi.org/10.1590/18071929/agriambi.v23n10p776-781

BRASIL - Ministério da Agricultura, Pecuária e Abastecimento (2009) Regras para análise de sementes. MAPA/ACS, 395p.

Burnham KP, Anderson DR (2004) Multimodel inference: understanding AIC and BIC in model selection. Sociological methods \& research 33(2):261-304. DOI: https://doi.org/10.1177/0049124104268644

Campos RC, Corrêa PC, Zaidan IR, Zaidan UR, Leite RA (2019) Moisture sorption isotherms of sunflower seeds: thermodynamic analysis. Ciência e Agrotecnologia 43(1):1-12. DOI: http://dx.doi.org/10.1590/14137054201943011619
Cavalcante MD, Plácido GR, Oliveira DEC, Freitas BSM, Cagnin C, Oliveira DS (2018) Isotherms and isostatic heat of foam-mat dried yellow mombin pulp. Revista Brasileira de Engenharia Agrícola e Ambiental 22(6):436-441. DOI: http://dx.doi.org/10.1590/18071929/agriambi.v22n6p436-441

Draper NR, Smith H (1998) Applied regression analysis. New York, John Wiley \& Sons, 712p.

Ferreira Junior WN, Resende O, Oliveira DEC, Costa LM (2018) Isotherms and isosteric heat desorption of Hymenaea stigonocarpa Mart. Seeds. Journal of Agricultural Science 10(10):504-512. DOI: http://dx.doi.org/10.5539/jas.v10n10p504

Gomes FP, Resende O, Sousa EP, Oliveira DEC, Araújo Neto FR (2018) Drying kinetics of crushed mass of 'jambu': Effective diffusivity and activation energy. Revista Brasileira de Engenharia Agrícola e Ambiental 22(7):499-505. DOI: http://dx.doi.org/10.1590/18071929/agriambi.v22n7p499-505

Goneli ALD, Corrêa PC, Oliveira GHH, Resende O, Mauad M (2016) Moisture sorption isotherms of castor beans. Part 1: Mathematical modeling and hysteresis. Revista Brasileira de Engenharia Agrícola e Ambiental 20(8):751-756. DOI: http://dx.doi.org/10.1590/18071929/agriambi.v20n8p751-756

Hall CW (1980) Drying and storage of agricultural crops. Westport, The AVI Publishing Company, 381p.

IUPAC - International Union of Pure and Applied Chemistry (1985) Reporting physisorption data for gas/solid systems with special reference to the determination of surface area and porosity (Recommendations 1984). Pure \& Applied Chemistry 57(4):603-619. DOI: https://doi.org/10.1515/iupac.57.0007

Labuza TP, Altunakar B (2007) Water Activity Prediction and Moisture Sorption Isotherms. In: Barbosa-Cánovas GV, Fontana Júnior AJ, Schmidt SJ, Labuza TP. Water activity in foods: fundamentals and applications. Blackwell Publishing Professional, p109-154. DOI: http://dx.doi.org/10.1002/9780470376454.ch5

Lins ADF, Rocha APT, Gomes JP, Feitosa RM, Araujo GT, Santos DC (2017) Adsorption isotherms of the red mombin powder produced in spouted bed dryer. Revista Brasileira de Engenharia Agrícola e Ambiental 21(8):562567. DOI: http://dx.doi.org/10.1590/18071929/agriambi.v21n8p562-567

Ly J, Sjofjan O, Djunaidi IH, Suyadi S (2017) Enriching nutritive value of tamarind seeds by Saccharomyces cerevisiae fermentation. Journal of Biochemical Technology 7(2):1107-1111.

Madamba PS, Driscoll RH, Bruckle KA (1996) Thin layer drying characteristics of garlic slices. Journal of Food Engineering 29(1):75-97. DOI:

https://doi.org/10.1016/0260-8774(95)00062-3

Mohapatra D, Rao PSA (2005) A thin layer drying model of parboiled wheat. Journal of Food Engineering 66(4):513-518. DOI:

https://doi.org/10.1016/j.jfoodeng.2004.04.023 
Quequeto WD, Resende O, Silva PC, Silva FAZ, Silva LCM (2019) Drying kinetics of noni seeds. Journal of Agricultural Science 11(5):250-258. DOI: http://dx.doi.org/10.5539/jas.v11n5p250

Oliveira JR, Cavalcanti Mata MER, Duarte MEM (2004) Isotermas de dessorção de grãos de feijão macassar verde (Vigna unguiculata (L.) Walpers), variedade sempreverde. Revista Brasileira de Produtos Agroindustriais 6(1):61-70. DOI: http://dx.doi.org/10.15871/15178595/rbpa.v6n1p61-70

Oliveira MM, Campos ARN, Gomes JP, Silva FLH (2005) Isotermas de sorção do resíduo agroindustrial de casca do abacaxi (Ananas comosus L. Mer). Revista Brasileira de Engenharia Agrícola e Ambiental 9(4):565-569. DOI: http://dx.doi.org/10.1590/S1415-43662005000400020

Oliveira DEC, Resende O, Campos RC, Donadon JR (2014) Obtenção e modelagem das isotermas de dessorção e do calor isostérico para sementes de arroz em casca. Científica 42(3):203-210. DOI: http://dx.doi.org/10.15361/1984-5529.2014v42n3p203-210

Oliveira DEC, Resende O, Costa LM, Ferreira Junior WN, Silva IOF (2017) Hygroscopicity of baru (Dipterix alata Vogel) fruit. Revista Brasileira de Engenharia Agrícola e Ambiental 21(4):279-284. DOI: http://dx.doi.org/10.1590/1807-1929/agriambi.v21n4p279-284

Schwarz G (1978) Estimating the dimension of a model. Annals of Statistics 6(2):461-464. DOI: http://dx.doi.org/10.1214/aos/1176344136
Silva HW, Costa LM, Resende O, Oliveira DEC, Soares RS, Vale LSR (2015) Higroscopicidade das sementes de pimenta (Capsicum chinense L.). Revista Brasileira de Engenharia Agrícola e Ambiental 19(8):780-784. DOI: http://dx.doi.org/10.1590/1807-1929/agriambi.v19n8p780-784

Sone Y, Sato K (1994) Measurement of oligosaccharides derived from Tamarind xyloglucan by competitive ELISA assay. Bioscience, Biotechnology and Biochemistry 58(12):2295-2296. DOI: http://dx.doi.org/10.1271/bbb.58.2295

Souza DG, Resende O, Moura LC, Ferreira Junior WN, Andrade JWS (2019) Drying kinetics of the sliced pulp of biofortified sweet potato (Ipomoea batatas L.). Engenharia Agrícola 39(2):176-181. DOI: http://dx.doi.org/10.1590/1809-4430eng.agric.v39n2p176-181/2019

Ullmann R, Resende O, Oliveira DEC, Costa LM, Chaves TH (2016) Higroscopicidade das sementes de sorgosacarino. Engenharia Agrícola 36(3):515-524. DOI: http://dx.doi.org/10.1590/1809-4430Eng.Agric.v36n3p515-524/2016

Zeymer JS, Corrêa PC, Oliveira GHH, Baptestini FM, Freitas RCP (2017) Desorption isotherms of Lactuca sativa seeds. Revista Brasileira de Engenharia Agrícola e Ambiental 21(8):568-572. DOI: http://dx.doi.org/10.1590/1807-1929/agriambi.v21n8p568-572 